\title{
Virulence comparison of different electrophero- types of infectious hematopoietic necrosis virus
}

\author{
S. E. LaPatra ${ }^{1,2, *}$, J. L. Fryer ${ }^{2}$, J. S. Rohovec ${ }^{2, * *}$ \\ ${ }^{1}$ Oregon Department of Fish and Wildlife, ${ }^{2}$ Department of Microbiology, Oregon State University, Corvallis, \\ Oregon 97331-3804, USA
}

\begin{abstract}
To define virulence of different electropherotypes of infectious hematopoietic necrosis virus (IHNV), chinook salmon Oncorhynchus tshawytscha and steelhead trout Oncorhynchus mykiss alevins were exposed by waterborne challenges to isolates of IHNV obtained from naturally infected adult rainbow trout $O$. mykiss, steelhead trout and chinook salmon at hatcheries in Oregon, Washington, Idaho and California, USA. Virulence was determined by comparing cumulative percent mortality and lethal dose $50 \%$ values for each IHNV isolate in both species of fish at 2 different mean body weights. Results showed that Columbia River basin IHNV electropherotypes (types 2 and 3) are virulent for steelhead trout and IHNV electropherotypes from southern Oregon and California (type 3) are virulent for chinook salmon. A type 1 electropherotype from the Columbia River basin was less virulent for both species. Isolates of type 3 IHNV exhibited differences in virulence depending on the geographic location from which they were obtained.
\end{abstract}

\section{INTRODUCTION}

Beginning in 1953, a disease of viral etiology was observed in cultured sockeye salmon Oncorhynchus nerka, chinook salmon Oncorhynchus tshawytscha and rainbow trout Oncorhynchus mykiss at hatcheries along the Pacific coast of North America. Early studies indicated that virus isolates from these epizootics were similar and because the hematopoietic tissues appeared to be most severely affected, the name infectious hematopoietic necrosis (IHN) was adopted (Wolf 1988). Infectious hematopoietic necrosis virus (IHNV) has caused extensive epizootics among hatcheryreared salmonid fish and occasional epizootics in wild salmonids (Williams \& Amend 1976). The virus has been reported in salmon and trout in Canada and in the United States including Oregon, Washington, Idaho, California and Alaska (Pilcher \& Fryer 1980). Infectious hematopoietic necrosis is a major disease of rainbow trout at commercial hatcheries in Idaho

\footnotetext{
- Present address: Clear Springs Foods, Inc., Research Division, PO Box 712, Buhl, Idaho 83316, USA

- Addressee for correspondence
}

(Busch 1983), and has spread throughout the Pacific Northwest in anadromous stocks of fish (Groberg \& Fryer 1983). The disease has also been observed in other areas of the United States (Wolf 1988), Taiwan (Chen et al. 1985), Japan (Sano 1976), and more recently in Italy (Bovo et al. 1987), France (Boudin Laurencin 1987), China (Luqi \& Zhizhuang 1988), and Korea (J. Park, Univ. of Ulsan, Korea, pers. comm.).

Although IHNV is distinct from other rhabdoviruses, analysis of strains using polyclonal antiserum has shown only 1 serotype. Isolates have been grouped by molecular weight differences in the structural proteins of the virion (Leong et al. 1981). This has resulted in the placement of IHNV isolates into 5 electropherotypes designated types 1 through 5 (Hsu et al. 1986).

Infectious hematopoietic necrosis epizootics in the Columbia River basin have occurred primarily in rainbow and steelhead Oncorhynchus mykiss trout (Groberg \& Fryer 1983), whereas losses in California have occurred almost exclusively in chinook salmon (W. H. Wingfield, California Department of Fish and Game, pers. comm.), although both chinook and steelhead are reared at hatcheries in these areas. Electropherotype 3 of IHNV is presumably responsible for 
Table 1. Isolates of infectious hematopoietic necrosis virus (IHNV) used in this study. IHNV concentrations expressed as log 10 pfu $\mathrm{ml}^{-1}$ of virus stocks used in fish exposures. Type: IHNV electropherotype

\begin{tabular}{|c|c|c|c|c|c|}
\hline Isolate label & Location (USA) & Host of origin & Year & IHNV concentration & Type \\
\hline $\mathrm{RBH}$ & Deschutes River, OR & Oncorhynchus mykiss a & 1986 & 7.8 & 1 \\
\hline COW & Cowlitz River, WA & O. mykiss d & 1981 & 7.3 & 2 \\
\hline $\mathrm{HAG}$ & Hagerman Valley, ID & O. mykiss ${ }^{\mathrm{b}}$ & 1983 & 7.8 & 2 \\
\hline DW & Clearwater River, ID & O. mykiss" & 1986 & 7.5 & 3 \\
\hline ER & Elk River, OR & O. tshawytscha & 1986 & 8.2 & 3 \\
\hline TR & Trinity River, CA & O. tshawytscha & 1986 & 8.3 & 3 \\
\hline
\end{tabular}

losses in chinook salmon (Chen et al. 1990) and is thought to be confined to California and certain rivers in southern Oregon (Hsu et al. 1986). Examination of a number of more recent isolates using the electropherotyping procedure detected only type $3 \mathrm{IHNV}$ in fish from rivers in California and southern Oregon. However, we also found type 3 IHNV from fish in the Columbia River basin. The purpose of this study was to determine the virulence of type 3 IHNV electropherotypes obtained from different geographic regions in chinook salmon and steelhead trout and compare these results to the virulence of type 1 and 2 strains in the same species of fish.

\section{MATERIALS AND METHODS}

Cell lines. Two fish cell lines were used for the isolation, propagation and identification of the virus isolates used in this study: the CHSE-214 line (ATCC CRL 1681) from chinook salmon (Lannan et al. 1984) and the EPC line derived from common carp Cyprinus carpio (Fijan et al. 1983). Both lines were propagated in Eagle's minimum essential medium (MEM, GIBCO Laboratories, Grand Island, NY, USA) supplemented with $10 \%$ fetal bovin serum (FBS, Hyclone Laboratories, Ogden, UT, USA; MEM-10), L-glutamine to $10 \mathrm{mM}, 50 \mathrm{U}$ penicillin $\mathrm{ml}^{-1}$, and $50 \mu \mathrm{g}$ streptomycin $\mathrm{ml}^{-1}$, and was buffered with $7.5 \%$ sodium bicarbonate (all from GIBCO) or tris- $\mathrm{HCl}$ (Sigma Chemical Company, St. Louis, MO, USA) to pH 7.5. For routine cell propagation, the CHSE-214 cells were incubated at $20^{\circ} \mathrm{C}$ and EPC cells at $25^{\circ} \mathrm{C}$. Viruses used for electropherotyping and virulence comparisons were grown in CHSE-214 cells at $16^{\circ} \mathrm{C}$ in MEM-5 (5\% FBS) and stored at $-70^{\circ} \mathrm{C}$. Stock concentrations for each virus isolate were determined by plaque assay in EPC cells (Burke \& Mulcahy 1980) before freezing.

Virus isolates and electropherotyping. Six isolates of IHNV were used in this study. The geographic location, host species, year of isolation, stock concentration, and electropherotype are given in Table 1.
Viruses were isolated and identified by methods previously described (Amos 1985). To determine the biochemical relatedness of the IHNV isolates, electrophoretic patterns of the structural polypeptides were compared. Virus purification was performed as described by Leong et al. (1981). Sodium dodecylsulfate polyacrylamide gel electrophoresis (SDS-PAGE) was performed under conditions similar to those of Laemmli (1970). Purified virus was mixed 1:1 in sample buffer $(120 \mathrm{mM}$ tris base, $4 \% \mathrm{w} / \mathrm{v}$ SDS, $10 \% \mathrm{v} / \mathrm{v} 2$ mercaptoethanol, $20 \% \mathrm{v} / \mathrm{v}$ glycerol and $3 \mathrm{mM}$ bromophenol blue) and placed in a boiling water bath for 2 to 3 min. Polypeptides were separated by electrophoresis for 6 to $7 \mathrm{~h}$ at $12 \mathrm{~mA}$ using a $12 \%$ separating gel and a $4.5 \%$ stacking gel. The silver staining method used was the same as that reported by Merril et al. (1981). The 6 isolates of IHNV used in the study were compared with known electropherotypes of IHNV identified as types 1 to 5 based on protein profiles described by Hsu et al. (1986). This same analysis was used to compare additional IHNV isolates obtained from other salmonid species being cultured at Dworshak National Fish Hatchery (Clearwater River, Idaho).

Fish. Alevin chinook salmon and steelhead trout (McKenzie River stock) with no previous history of IHNV were provided by the Oregon Department of Fish and Wildlife. Fish were held at the Oregon State University Fish Diseases Laboratory in $12^{\circ} \mathrm{C}$ fishpathogen-free well water where experiments were conducted. Fish were tested for IHNV susceptibility at 2 different mean weights. Chinook salmon were tested first at 0.6 and $1.4 \mathrm{~g}$ mean weight followed by steelhead trout at 0.4 and $1.8 \mathrm{~g}$.

Exposure of fish to virus. Virulence of the 6 IHNV isolates for chinook salmon and steelhead trout was determined by waterborne exposures to virus. Groups of 30 fish were exposed to 4 dilutions of virus prepared in MEM in containers with 1 I of static well water to achieve concentrations of approximately $10^{2}$ to $10^{5}$ plaque-forming units (pfu) $\mathrm{ml}^{-1}$. Stock virus concentrations were determined at each test ( 4 total). Fish in control groups were treated the same but only MEM 
was added. During the $12 \mathrm{~h}$ exposure, water was aerated and containers were partially immersed in free-flowing water to maintain a constant temperature. After the exposure period, the contents of each container were placed into a 68 I fiberglass aquarium receiving single-pass water flowing at a rate of approximately $11 \mathrm{~min}^{-1}$. Fish were fed a diet of Oregon Moist Pellet twice daily and observed for signs of IHNV infection. Dead fish were removed daily, weighed, and examined for virus. Cumulative percent mortality and $50 \%$ lethal dose $\left(\mathrm{LD}_{50}\right)$ values (Reed \& Muench 1938) were calculated and cumulative mortality data were analyzed by logistic regression with the statistical software package 'GLIM' (Royal Statistical Society 1985).

Isolation and quantitation of virus. All dead fish were examined for virus as described by Amos (1985). Quantitation of virus used in fish exposures or isolated from dead fish was accomplished by plaque assay. For isolation, cell cultures were observed daily for $10 \mathrm{~d}$ for the characteristic cytopathology produced by IHNV. Isolates from each experiment were confirmed as IHNV by alpha neutralization tests (Rovozzo \& Burke 1973) with specific rabbit antiserum.

\section{RESULTS}

\section{Electropherotyping of virus isolates}

Electrophoretic profiles of the 6 virus isolates by SDS-PAGE showed differences in the structural proteins. The RBH isolate had a low molecular weight nucleocapsid $(\mathrm{N})$ protein characteristic of type 1 . The COW and HAG isolates had higher molecular weight $\mathrm{N}$ proteins (type 2), while ER and TR had N molecular weights typical of type 3 (Fig. 1). All isolates obtained from infected salmonid fish at Dworshak National Fish Hatchery (DW) were type 3 (Fig. 2).

\section{Species susceptibility and virus virulence}

Chinook salmon infected with the RBH, COW, HAG, and DW isolates had, in general, a lower cumulative percent mortality at both weights than chinook infected with the ER and TR isolates. Steelhead trout in- fected with RBH, ER, and TR had a lower cumulative percent mortality at both weights than steelhead infected with COW, HAG, and DW. Although accurate $\mathrm{LD}_{50}$ values could not be calculated in all cases, a trend was evident. The ER and TR isolates had lower $\mathrm{LD}_{50}$ values for chinook salmon at $0.6 \mathrm{~g}$ mean body weight and the COW, HAG, and DW isolates had lower $\mathbf{L D}_{50}$ values for steelhead trout at $0.4 \mathrm{~g}$ mean body weight (Table 2). All isolates were less virulent in chinook at the $1.4 \mathrm{~g}$ size and steelhead at the $1.8 \mathrm{~g}$ size but similar species susceptibility and virus virulence differences were observed (data not shown).

Chinook salmon ( $0.6 \mathrm{~g}$ mean weight) exposed to the highest concentration showed a significant difference between groups of isolates ( $p<0.005)$, assuming binomial error. Cumulative mortalities for ER and TR isolates were significantly greater than cumulative mortalities for the other isolates. A model with a higher common mortality rate for the ER and TR isolates and a lower common mortality for RBH, COW, HAG, and DW isolates fits the data (lack of fit, $p>0.20$ assuming bino- 
Table 2. Cumulative percent mortality $(n=30)$ and viral dose that caused $50 \%$ mortality $\left(\mathrm{LD}_{50}\right)$ of chinook salmon Oncorhynchus tshawytscha and steelhead trout $O$. mykiss infected with 6 isolates of infectious hematopoietic necrosis virus (IHNV) at the smallest fish size tested. IHNV concentrations expressed as $\log _{10}$ dilution of stock virus concentration. LD $_{50}$ expressed as $\log _{10}$ values. See Table 1 for isolate symbols. C: control

\begin{tabular}{|c|c|c|c|c|c|c|c|c|}
\hline \multirow[t]{2}{*}{ Species } & \multirow{2}{*}{$\begin{array}{c}\text { Mean weight } \\
\text { (g) }\end{array}$} & \multirow{2}{*}{$\begin{array}{l}\text { Age } \\
\text { (d) }\end{array}$} & \multirow[t]{2}{*}{ Isolate } & \multicolumn{4}{|c|}{ Concentrations of IHNV at exposure: } & \multirow[t]{2}{*}{$\mathrm{LD}_{50}$} \\
\hline & & & & -2 & -3 & -4 & -5 & \\
\hline \multirow[t]{7}{*}{ Chinook salmon } & 0.6 & 48 & $\mathrm{RBH}$ & 40 & 23 & 3 & 0 & $>5.8$ \\
\hline & & & COW & 17 & 7 & 7 & 13 & $>5.3$ \\
\hline & & & $\mathrm{HAG}$ & 17 & 7 & 3 & 0 & $>5.8$ \\
\hline & & & DW & 20 & 23 & 7 & 0 & $>5.5$ \\
\hline & & & ER & 93 & 73 & 13 & 7 & 4.8 \\
\hline & & & TR & 93 & 57 & 44 & 37 & 4.8 \\
\hline & & & $\mathrm{C}$ & 0 & & & & \\
\hline \multirow[t]{7}{*}{ Steelhead trout } & 0.4 & 28 & $\mathrm{RBH}$ & 30 & 53 & 43 & 3 & 4.5 \\
\hline & & & COW & 100 & 87 & 53 & 63 & $<2.3$ \\
\hline & & & $\mathrm{HAG}$ & 97 & 93 & 59 & 77 & $<2.8$ \\
\hline & & & DW & 100 & 87 & 73 & 47 & 2.8 \\
\hline & & & ER & 67 & 27 & 7 & 3 & 5.8 \\
\hline & & & TR & 50 & 17 & 27 & 10 & 6.4 \\
\hline & & & C & 0 & & & & \\
\hline
\end{tabular}

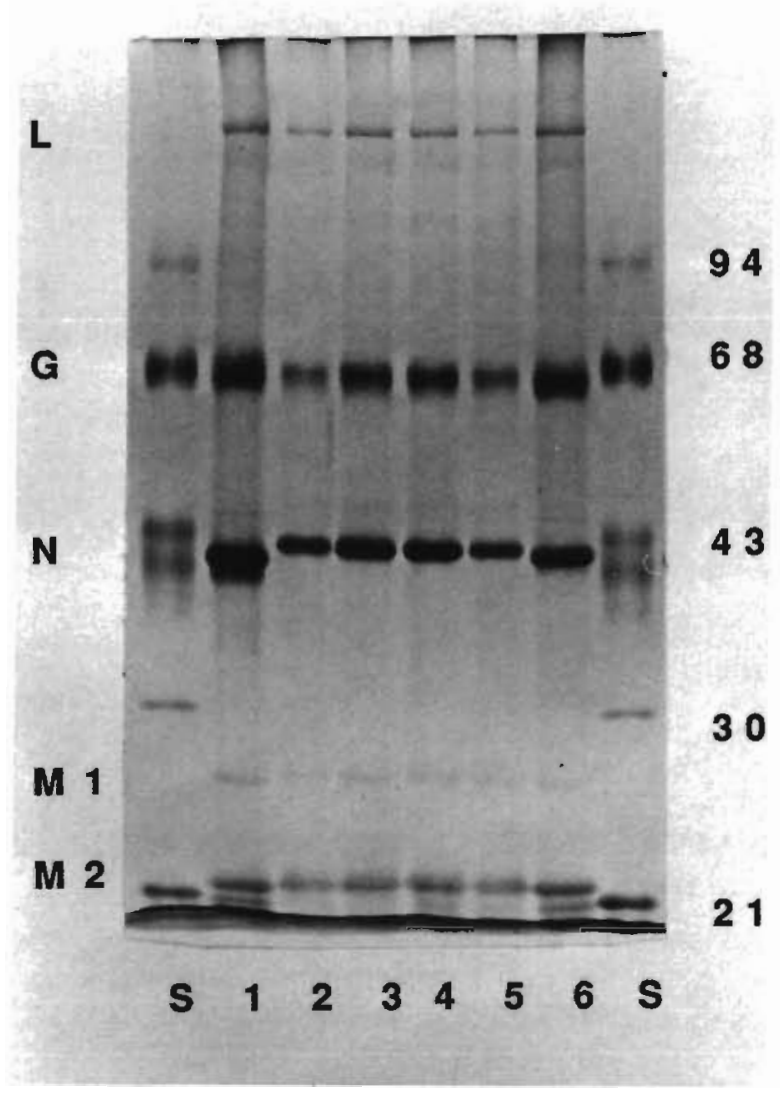

Fig. 2. Electrophoretic profile of different isolates of infectious hematopoietic necrosis virus obtained from infected fish at Dworshak National Fish Hatchery (Clearwater River, Idaho) and IHNV electropherotype 1 and 2 standards. Lane representations are $\mathrm{S}$ : molecular weight standards; 1 : type $1 ; 2$ : isolate from steelhead trout adult Oncorhynchus mykiss; 3: isolate from steelhead trout juvenile; 4 : isolate from chinook salmon adult $O$. tshawytscha; 5 : isolate from rainbow trout juvenile O. mykiss; 6 : type 2 mial error). Likewise, steelhead trout $(0.4 \mathrm{~g}$ mean weight) exposed to the highest concentration showed a significant difference between groups of isolates ( $p<0.005$ assuming binomial error). A model with 3 groups best fit the data (lack of fit, $p>0.20$ ). The highest mortality was in a group exposed to COW, HAG, and DW isolates, the next highest rate was a group with ER and TR isolates, and the lowest mortality was observed for the RBH isolate.

\section{Virus quantitation and confirmation}

Stock virus concentrations used in fish exposures were $<10^{0.4} \mathrm{pfu} \mathrm{ml}^{-1}$ at each test compared to virus concentrations determined at freezing. Virus was isolated from dead fish in concentrations ranging from $10^{39}$ to $10^{7.1} \mathrm{pfu} \mathrm{g}^{-1}$ of tissue from more than $90 \%$ of all mortalities. The isolates were confirmed as IHNV by serum neutralization and considered to be the cause of death.

\section{DISCUSSION}

The virulence of IHNV isolates for different salmonid species has been reported (Rucker et al. 1953, Wingfield et al. 1970, Chen et al. 1990) but no attempt was made to correlate virulence with an IHNV strain typing scheme. LaPatra et al. (1990a) compared virulence of IHNV electropherotypes 1 and 2 in different sizes of kokanee salmon Oncorhynchus nerka and rainbow trout. The type 1 strain was more virulent for kokanee, whereas, type 2 was more virulent for rainbow trout. Virus virulence differences were more evi- 
dent in larger fish tested because of decreased susceptibility of salmonids with increasing size and age, particularly to less virulent IHNV strains. Another study compared the pathogenicity of electropherotype 1,2 , and 3 strains in alevin rainbow trout. The results showed that the type 2 strain was most virulent for rainbow trout, in agreement with previous studies (LaPatra et al. 1990b). Results of the study reported here showed that Columbia River basin IHNV electropherotypes (types 2 and 3; COW, HAG, and DW) were more virulent for steelhead trout, whereas, IHNV electropherotypes from southern Oregon and California (type 3; ER and TR) were more virulent for chinook salmon. A type 1 electropherotype $(\mathrm{RBH})$ was less virulent for both species. Among the 3 isolates of type 3 IHNV tested, differences in virulence varied depending on the geographic location from which they were obtained. The host species from which the isolate was obtained also varied but most likely had no effect on virulence because other studies have shown that adult salmonids of different species in the same geographical area can be asymptomatic carriers of identical electropherotypes of IHNV (Hsu et al. 1986, Ristow \& Arnzen de Avila 1991). Additionally, salmonid species susceptibility studies which compared IHNV isolates of different host origin showed that the host species from which the IHNV isolate was obtained has a negligible effect on pathogenicity for other salmonids (LaPatra et al. 1989, 1990a, Chen et al. 1990, Traxler et al. 1993).

Hsu et al. (1985) noted that the nucleoprotein (N) molecular weight differences detected for different IHNV isolates (Leong et al. 1981) was a unique characteristic. For other rhabdoviruses, such as rabies and vesicular stomatitis virus, the virion glycoprotein (G) molecular weights vary among strains, and pathogenicity of rabies can be determined with G-specific monoclonal antibodies (Dietzschold et al. 1983). While differences in $G$ could not be detected among strains of IHNV with polyvalent antisera (Engelking et al. 1991), they were detected with G-specific monoclonal antibodies (Winton et al. 1988, Ristow \& Arnzen de Avila 1991) but virulence of these isolates was not tested. Recent studies comparing $G$ gene nucleic acid sequences of IHNV isolates from California, Oregon, Washington and Idaho indicated this gene was highly conserved (J. R. Winton, U.S. Fish and Wildlife Service, pers. comm.). This suggests that virulence differences observed for IHNV may not be due to differences in G Examining characteristics of both the $\mathrm{N}$ and $\mathrm{G}$ proteins could accurately define virulence and explain the discrepancy observed with virulence differences seen in type 3 IHNV strains used in this study.

Another explanation for this discrepancy is the difficulty in distinguishing type 2 and 3 strains by SDS-
PAGE. There is approximately a 2000 Da molecular weight difference between the $N$ protein of types 1 and 2 but only a 500 to 1000 Da difference between types 2 and 3 . This latter difference is very small and can be difficult to detect consistently by standard SDSPAGE. The use of gradient gels may allow better separation of $\mathrm{N}$ proteins by SDS-PAGE

Monoclonal antibodies produced against the $\mathrm{N}$ protein of electropherotypes of IHNV may allow more accurate serological strain differentiation. Ristow \& Arnzen de Avila (1991) examined many isolates from fish from throughout the Pacific Northwest using monoclonal antibodies and detected heterogeneity in both the $N$ and $G$ proteins of the virus. However, these epitope differences were not correlated with virulence for a particular species of salmonid. Future studies should focus on defining the antigenic and genetic differences of $\mathrm{N}$ that could be responsible for virulence for particular species of salmonids. This information will be important in the development of more accurate IHNV strain differentiation methods, effective vaccines, and other biotechnologically derived control strategies.

Acknowledgements. The authors thank $\mathrm{N}$ Wood (International Aquaculture Research Center, Hagerman Valley Idaho) and J. Lientz (U.S. Fish and Wildlife Service, Anahaska, Idaho) for providing isolates of IHNV, the Oregon Department of Fish and Wildlife for supplying the fish, $\mathrm{C}$ Pereira (Department of Statistics, Oregon State University) for help with the statistical analysis, and C. Pelroy and E. Thompson for typing the manuscript. This work was sponsored by the Oregon Sea Grant through the NOAA Office of Sea Grant, Department of Commerce, under grant No NA85AA-D-5G095 (Project No. R/FSD-10) and a grant from the Oregon Department of Fish and Wildlife under PL 89-304, the Anadromous Fish Act. Oregon Agricultural Experiment Station Technical Paper No. 8828.

\section{LITERATURE CITED}

Amos, K. H. (1985). Procedures for the detection and identification of certain fish pathogens, 3rd edn. Fish Health Section, American Fisheries Society, Corvallis, p. 6-21

Baudin Laurencin, F. (1987). IHN in France. Bull. Eur. Ass. Fish Pathol. 7: 104

Bovo, G., Giorgetti, G., Jørgensen, P. E. V., Olesen, N. J (1987). Infectious hematopoietic necrosis: first detection in Italy. Bull. Eur. Ass. Fish Pathol. 7: 124

Burke, J. A., Mulcahy, D. (1980). Plaquing procedure for infectious hematopoietic necrosis virus. Appl. environ. Microbiol. 39: 872-876

Busch, R. A. (1983). Viral disease considerations in the commercial trout industry in Idaho. In: Leong, J. C., Barila, T. $Y$. (eds.) Workshop on viral diseases of salmonid fishes in the Columbia River basin, 7-8 October 1982, Portland, Oregon. Special Publication, Bonneville Power Administration, Portland, p. 84-100

Chen, M. F., Aikens, C. M., Fryer, J. L., Rohovec, J. S. (1990) Virulence of four isolates of infectious hematopoietic 
necrosis virus in salmonid fishes and comparative replication in salmonid fish cell lines. Calif. Fish Game 76 : $137-145$

Chen, S. N., Kou, G. H., Hedrick, R. P., Fryer, J. L. (1985). The occurrence of viral infection of fish in Taiwan. In: Ellis, A. E. (ed.) Fish and shellfish pathology. Academic Press, New York, p. 313-318

Dietzschold, B., Wunner, W. H., Wikto, T. J., Lopes, D., Lafon, M., Smith, C. L., Koprowski, H. (1983). Characterization of an antigenic determinant of the glycoprotein that correlates with pathogenicity of rabies virus. Proc. Natl Acad. Sci. U.S.A. 80: 70-74

Engelking, H. M., Harry, J. B., Leong, J. L. (1991). Comparison of representative strains of infectious hematopoietic necrosis virus by serological neutralization and cross-protection assays. Appl. environ. Microbiol. 57: $1372-1378$

Fijan, N., Sulimanovic, D., Bearzotti, M., Muzinic, D., Zwillenberg, L. D., Chilmonczyk, S., Vautherot, J. F., de Kinkelin, P. (1983). Some properties of the Epithelioma papulosum cyprini (EPC) cell line from carp Cyprinus carpio. Annls Virol. Inst. Pasteur 134E: 207-220

Groberg, W. J., Fryer, J. L. (1983). Increased occurrences of infectious hematopoietic necrosis virus in fish at Columbia River basin hatcheries: 1980-1982. Sea Grant College Program, Oregon State University, Corvallis, Technical Paper No. 6620

Hsu, Y. L., Engelking, H. M., Leong, J. C. (1985). Analysis of the quantity and synthesis of the virion proteins of infectious hematopoietic necrosis virus. Fish Pathol. 20: $331-338$

Hsu, Y L., Engelking, H. M., Leong, J. C. (1986). Occurrence of different types of infectious hematopoietic necrosis virus in fish. Appl. environ. Microbiol. 52: 1353-1361

Laemmli, U. K. (1970). Cleavage of structural proteins during the assembly of the head of bacteriophage T4. Nature 227 : $680-685$

Lannan, C. N., Winton, J. R., Fryer, J. L. (1984). Fish cell lines: establishment and characterization of nine cell lines from Salmonids. In Vitro 20(9): $671-676$

LaPatra, S. E., Fryer, J. L., Wingfield, W. H., Hedrick, R. P. (1989). Infectious hematopoietic necrosis (IHNV) in coho salmon. J. aquat. Anim. Hlth 1: 227-280

LaPatra, S. E., Groberg, W. J., Rohovec, J. S., Fryer, J. L. (1990a). Size-related susceptibility of salmonids to two strains of infectious hematopoietic necrosis virus. Trans. Am. Fish. Soc. 119: 25-30

LaPatra, S. E., Groff, J. M., Fryer, J. L., Hedrick, R. P. (1990b) Comparative pathogenesis of three strains of infectious hematopoietic necrosis virus in rainbow trout Oncorhynchus mykiss. Dis. aquat. Org. 8: 105-112

Responsible Subject Editor: F. M. Hetrick, College Park, Maryland, USA
Leong, J. C., Hsu, Y. L., Engelking, H. M., Mulcahy, D. (1981). Strains of infectious hematopoietic necrosis (IHN) virus may be identified by structural protein differences. In: Anderson, D. P., Hennessen, W. (eds.) Developments in biological standardization, Vol. 49. S. Karger, Basel, p. $43-55$

Luqi, N., Zhizhuang, Z. (1988). The epidemiology of IHN and IPN of rainbow trout in northeast China. Shui Chan Xue Bao (J. Fish. China) 12: $327-332$

Merril, C. R., Goldman, D., Sedman, S. A., Ebert, H. M. (1981). Ultrasensitive stain for proteins in polyacrylamide gels shows regional variation in cerebrospinal fluid proteins. Science 211: 143-144

Pilcher, K. S., Fryer, J. L. (1980). The viral diseases of fish: a review through 1978. CRC crit. Rev. Microbiol. 7: 287-364

Reed, L. J., Muench, H. (1938). A simple method of estimating fifty percent endpoints. Am. J. Hygiene 27: 493-497

Ristow, S. S., Arnzen de Avila, J. (1991). Monoclonal antibodies to the glycoprotein and nucleoprotein of infectious hematopoietic necrosis virus (IHNV) reveal differences among isolates of the virus by fluorescence, neutralization, and electrophoresis. Dis. aquat. Org. 11: 105-115

Rovozzo, G. C., Burke, C. N. (1973). Basic virological techniques. Prentice-Hall, Englewood Cliffs

Royal Statistical Society (1985). Generalized Linear Interactive Modeling (GLIM) system, Release $3.77 \mathrm{edn}$. Numerical Algorithms Group, Inc., Downers Grove, IL

Rucker, R. R., Whipple, W. J., Parvin, J. R., Evans, C. A. (1953) A contagious disease of salmon possibly of virus origin Fish. Bull. Fish Wildl. Serv. U.S. 54 : 35-46

Sano, T. (1976). Viral diseases of cultured fishes in Japan. Fish Pathol. 10: 221-226

Traxler, G. S., Roome, J. R., Kent, M. L. (1993). Transmission of infectious hematopoietic necrosis virus in sea water. Dis. aquat. Org. (in press)

Williams, I., Amend, D. F. (1976). A natural epizootic of infectious hematopoietic necrosis in fry of sockeye salmon. Oncorhynchus nerka, at Chilko Lake, British Columbia J. Fish. Res. Bd Can. 33: 1564-1567

Wingfield, W. H., Nims, L., Fryer, J. L., Pilcher, K. S. (1970) Species specificity of the sockeye salmon virus (Oregon strain) and its cytopathic effect in salmonid cell lines. In: Snieszko, S. F. (ed.) A symposium on diseases of fish and shellfishes. Am. Fish. Soc. Spec. Publ., Washington, DC, p. 319-325

Winton, J. R., Arakawa, C. K., Lannan, C. N., Fryer J. L. (1988). Neutralizing monoclonal antibodies recognize antigenic variants among isolates of infectious hematopoietic necrosis virus. Dis. aquat. Org 4: 199-204

Wolf, K. (1988). Fish viruses and fish viral diseases. Cornell University Press, Ithaca, p. 83-114

Manuscript first received: December 9, 1992 Revised version accepted: March 23, 1993 